\title{
Spindle cell carcinoma of tongue
}

\author{
Antony Raj James, ${ }^{1}$ Raghul Sekar 다, ' Sivaraman Ganesan, \\ Bheemanathi Hanuman Srinivas ${ }^{2}$
}

${ }^{1}$ Department of Otolaryngology, Jawaharlal Institute of Postgraduate Medical Education and Research, Pondicherry, India ${ }^{2}$ Department of Pathology, JIPMER, Pondicherry, India

\section{Correspondence to}

Dr Raghul Sekar;

raghul8020@gmail.com

Accepted 7 November 2021

\section{DESCRIPTION}

A 55-year-old man presented to the ear, nose and throat clinic with complaints of growth in the left side of the tongue for the past 3 months. The growth was insidious in onset, rapidly progressive in size, and associated with speech and swallowing difficulties. He had history of multiple choking episodes while sleeping. He had a history of smoking and alcohol intake regularly for the past 20 years. On physical examination, there was a $5 \times 5$ $\mathrm{cm}$ polypoidal, pedunculated mass arising from the left lateral border of the tongue attached by a stalk (figure 1A,B). The mass was firm in consistency. There were no palpable neck nodes. Biopsy showed a poorly differentiated carcinoma with spindle cells suggestive of spindle cell variant of squamous cell carcinoma (SCC) (figure 2A,B). Imaging showed a $3.8 \times 0.8 \times 1.5 \mathrm{~cm}$ mass in the left lateral border of the tongue. The lesion was $1.5 \mathrm{~cm}$ from the midline raphe and $1.5 \mathrm{~cm}$ from the tip of the tongue. No extension to the posterior third of the tongue. There was no lymphadenopathy in the neck, and chest imaging was negative. The patient underwent wide local excision with elective neck dissection. Postoperative biopsy was T3N0M0 spindle cell variant of SCC with immunohistochemistry showing strong vimentin and cytokeratin positivity with p63 negative tumour cells (figure $3 \mathrm{~A}-\mathrm{C}$ ).

Spindle cell carcinoma, also known as sarcomatoid carcinoma, is an exceedingly rare variant of SCC with a unique clinicopathological profile. It is an aggressive and poorly differentiated variant that predominantly occurs in the larynx. ${ }^{1}$ The incidence of spindle cell carcinoma on the oral cavity is very rare and accounts for less than $1 \%$ of all oral cavity tumours. It presents in the sixth and seventh decades of life and is more common in men. It has a unique clinical appearance compared with other SCC. It presents as a polypoid, exophytic or

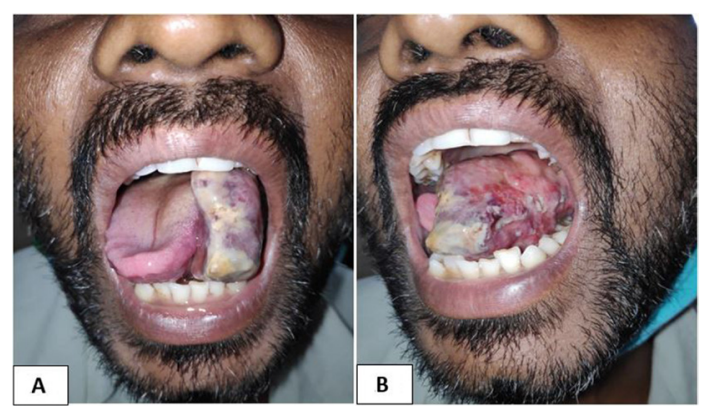

Figure 1 (A) Gross appearance showing a slough covered smooth, polypoidal mass attached to the left lateral border of tongue and (B) lateral surface of the mass showing areas of haemorrhage.
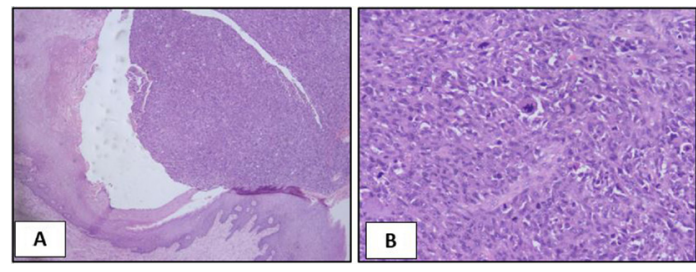

Figure 2 (A) Sections show sheets of tumour cells with overlying squamous epithelium (H\&EX40) and (B) round to oval cells which show marked degree of nuclear atypical and frequent mitotic figures (arrow head) (H\&EX200).

pedunculated mass. It is also known as pseudo carcinoma, polypoid SCC and collusion tumour. ${ }^{2}$ The spindle cell component arises as an atypical reactive proliferation of the stroma called 'pseudosarcoma'. ${ }^{4}$ The spindle cells and epithelial cells arise from different stem cells hence the name collision tumour. ${ }^{5}$ The risk factors associated with spindle cell carcinoma formation are smoking, alcohol and previous radiotherapy. Oral and oropharyngeal tumours present as painful or painless masses with dysphagia or bleeding. 6 Regional metastases can occur in about $25 \%$ of cases.

Histologically, it can present as a monophasic spindled, pleomorphic or a biphasic tumour where epithelial changes from dysplasia to invasive carcinoma are admixed with spindle cells. It shows hypercellularity with streaming fascicles of spindle cells in a sarcomatous appearance. Immunohistochemistry is helpful to know the histiogenesis of the spindle cell in this tumour. Epithelial markers that show positivity are keratin and epithelial membrane antigen, while mesenchymal markers include vimentin, desmin and S-100.

Aggressive surgical resection is considered a mainstay of treatment for this tumour. Surgery followed by radiotherapy is considered for the best long-term outcome. Radiotherapy is considered in inoperable cases and positive surgical margins with extensive nodal metastasis. The factors which favour a good prognosis in spindle cell carcinoma

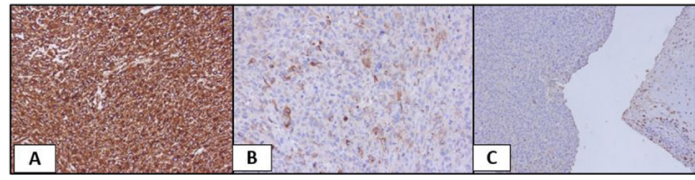

Figure 3 (A) IHC with vimentin show strong cytoplasm positivity (DABx100), (B) cytokeratin IHC show scattered tumour cells show positivity (DABx200) and (C) shows P63 IHC negative in tumour cells and positive in overlying epithelium (DABx100). IHC, Immunohistochemistry. 
are low-stage, small-size, absence of previous radiation, superficial location, polypoid and exophytic growth. A high recurrence rate of 70\%-75\% has been reported, and hence close follow-up is essential. ${ }^{8}$ There is a noticeable difference in prognosis and overall survival of spindle cell carcinoma compared with SCC. The incidence of metastasis is $36 \%$, and about $30 \%$ of all oral cases ended with mortality within 1 year. $^{78}$

The differential diagnosis for this tumour can be

- Reactive epithelial proliferation

- Fibromatosis

- Fibrous histiocytoma

- Rhabdomyosarcoma

- Chondrosarcoma

\section{Patient's perspective}

I noticed a mass on my tongue which was rapidly growing in size. I consulted the ENT doctors who took a biopsy and told me it is a rare aggressive variant tumour. I underwent immediate surgery and I am on regular follow-up with my doctors. I m totally relieved of my symptoms now.

\section{Learning points}

- Spindle cell carcinoma is a rare and aggressive variant of squamous cell carcinoma.

- It accounts for less than $1 \%$ of all oral cavity tumours.

- It has a unique clinicopathological profile with a polypoidal, pedunculated appearance.

- Histologically it stains for both epithelial and mesenchymal markers.

- Aggressive surgical treatment with or without radiotherapy with close follow-up is essential to treat this tumour.
Contributors Conception and design done by ARJ and BHS. Acquisition of data or analysis and interpretation of data by ARJ and RS. Drafting the article is done by RS, SG and BHS. Final approval of the version is done by SG and RS.

Funding The authors have not declared a specific grant for this research from any funding agency in the public, commercial or not-for-profit sectors.

Competing interests None declared.

Patient consent for publication Consent obtained directly from patient(s).

Provenance and peer review Not commissioned; externally peer reviewed.

Case reports provide a valuable learning resource for the scientific community and can indicate areas of interest for future research. They should not be used in isolation to guide treatment choices or public health policy.

\section{ORCID iD}

Raghul Sekar http://orcid.org/0000-0002-9514-6189

\section{REFERENCES}

1 Stelow EB, Mills SE. Squamous cell carcinoma variants of the upper aerodigestive tract. Am J Clin Pathol 2005;124 Suppl:S96-109.

2 Neville BW. Oral and maxillofacial pathology. 3. Saunders/Elsevier, 2009.

3 Anderson CE, Al-Nafussi A. Spindle cell lesions of the head and neck: an overview and diagnostic approach. Diagn Histopathol 2009;15:264-72.

$4 \mathrm{Su} \mathrm{H-H,} \mathrm{Chu} \mathrm{S-T,} \mathrm{Hou} \mathrm{Y-Y,} \mathrm{et} \mathrm{al.} \mathrm{Spindle} \mathrm{cell} \mathrm{carcinoma} \mathrm{of} \mathrm{the} \mathrm{oral} \mathrm{cavity} \mathrm{and}$ oropharynx: factors affecting outcome. J Chin Med Assoc 2006;69:478-83.

5 Silvestri SB, Carrau RL, Peel R, et al. Spindle cell carcinoma of the larynx with actinomyces chondritis of the larynx and trachea. Otolaryngol Head Neck Surg 2006;134:345-7.

6 Miyahara H, Tsuruta Y, Yane K, et al. Spindle cell carcinoma of the larynx. Auris Nasus Larynx 2004;31:177-82.

7 Palla B, Suhaym O, Majeed N, et al. Spindle cell variant squamous cell carcinoma of the oral cavity: case presentation and review of literature. Oral Maxillofac Surg Cases 2020:6:100174.

8 Sarma A, Das R, Sharma JD, et al. Spindle cell carcinoma of the head and neck: a clinicopathological and immunohistochemical study of 40 cases. J Cancer Ther 2012;03:1055-9.

Copyright 2021 BMJ Publishing Group. All rights reserved. For permission to reuse any of this content visit https://www.bmj.com/company/products-services/rights-and-licensing/permissions/ BMJ Case Report Fellows may re-use this article for personal use and teaching without any further permission.

Become a Fellow of BMJ Case Reports today and you can:

- Submit as many cases as you like

- Enjoy fast sympathetic peer review and rapid publication of accepted articles

- Access all the published articles

- Re-use any of the published material for personal use and teaching without further permission

Customer Service

If you have any further queries about your subscription, please contact our customer services team on +44 (0) 2071111105 or via email at support@bmj.com.

Visit casereports.bmj.com for more articles like this and to become a Fellow 